\section{Kidney \\ Blood Pressure Research}

Kidney Blood Press Res 2012;36:200-208

\begin{tabular}{l|l}
\hline DOI: $10.1159 / 000343409$ & (c) 2012 S. Karger AG, Basel \\
\hline
\end{tabular}

www.karger.com/kbr

200

Original Paper

\title{
ADMA, SDMA and L-arginine/ADMA Ratio but not DDAH Genetic Polymorphisms are Reliable Predictors of Diabetic Nephropathy Progression as Identified by Competing Risk Analysis
}

\author{
Veronika Tanhäuserováa Josef Tomandl ${ }^{\mathrm{b}} \quad$ Lukáš Pácal $^{\mathrm{a}} \quad$ Martin Klepárník ${ }^{\mathrm{b}}$ \\ Denisa Malúškovác Vendula Bartákováa Katarína Kuricováa Jitka Řehořovád \\ Soňa Štěpánkovád Jan Svojanovskýe Jindřich Olšovskýe Jana Bělobrádkovád \\ Darja Krusováe Michal Jurajda ${ }^{a}$ Jan Mužík ${ }^{c}$ Tomáš Pavlík ${ }^{c}$ Kateřina Kaňkováa
}

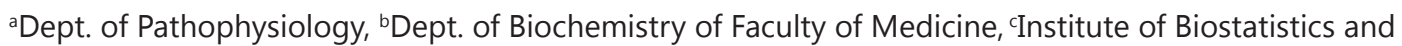
Analyses, Masaryk University Brno, Czech Republic, dDept. of Internal Medicine-Gastroenterology,

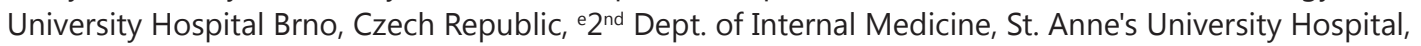
Brno, Czech Republic

\section{Key Words}

Asymmetric dimethylarginine - Competing risk analysis - Diabetic nephropathy • Dimethylarginine dimethylaminohydrolase $\cdot$ Polymorphism • Symmetric dimethylarginine

\begin{abstract}
Background/Aims: Complex interplay of genetic and (patho)physiological factors influence availability of nitric oxide during the development and progression of diabetic complications. We assessed predictive value of commonly studied methylated asymmetric and symmetric dimethylarginines (ADMA and SDMA) and selected single nucleotide polymorphisms (SNPs) in dimethylarginine dimethylaminohydrolase (DDAH) 1 and 2 genes for the progression of diabetic nephropathy (DN). Methods: A total of 341 type 1 and type 2 diabetes patients with variable degree of kidney disease were included at baseline. Plasma levels of ADMA, SDMA and L-arginine were measured and six tagging SNPs in DDAH1 and 2 were determined. Progression of DN was defined as a transition from any given stage to a more advanced stage of albuminuria. Competing risk analysis was applied. Results: Plasma levels of ADMA and SDMA significantly correlated with GFR. No significant genotype-phenotype relationship was ascertained for ADMA and DDAH variants, but SNP rs805304 exhibited marginally significant association with DN. ADMA, SDMA and L-arginine/ADMA ratio standardised to GFR were
\end{abstract}




\section{Kidney Blood Pressure Research}

Kidney Blood Press Res 2012;36:200-208

\begin{tabular}{l|l}
\hline DOI: $10.1159 / 000343409$ & (C) 2012 S. Karger AG, Basel
\end{tabular}

Published online: November 11, 2012

www.karger.com/kbr

201

Tanhäuserová/Tomandl/Pácal et al.: Methylated Arginines are Predictors of Diabetic Nephropathy Progression

identified as significant predictors of DN progression but not GFR decline using multivariate competing risk analysis. Conclusions: In our study we confirmed potentially significant role of ADMA and SDMA for the assessment of risk of DN progression in European diabetic population.

Copyright $@ 2012$ S. Karger AG, Basel

\section{Introduction}

Altered production of nitric oxide (NO) plays a pathogenic role in numerous pathological conditions including hyperglycaemia-related complications of diabetes mellitus (DM) and specifically in the pathogenesis of diabetic nephropathy (DN) due to the key role of NO as a local vasodilator of afferent arteriole. Decreased bioavailability of NO leads to the endothelial dysfunction and thus contributes to the development of micro- and macroangiopathy in DM [1]. Enzyme nitric oxide synthase (NOS) catalyses the production of NO from L-arginine. Several factors influence NO bioavailability: amount of NOS substrate (L-arginine) and cofactor (tetrahydrobiopterine), NOS activity and also production of reactive oxygen species capable of NO inactivating. NO synthesis can be blocked by L-arginine analogues $\mathrm{N}$-monomethyl-L-arginine (L-NMMA), asymmetric dimethylarginine (ADMA) and symmetric dimethylarginine (SDMA). All three substances arise from proteolysis of methylated proteins and likely act as competitive inhibitors of L-arginine transport across the cell membrane causing decreased intracellular L-arginine availability [2]. L-NMMA and ADMA but not SDMA act as competitive inhibitors of NOS. Plasma levels of ADMA are 10-times greater than that of L-NMMA therefore ADMA is assumed to have a more important role in vivo.

Methylated arginines are eliminated by renal excretion (SDMA almost entirely but only $10 \%$ of L-NMMA and ADMA), the latter two are metabolized by two isoforms of enzyme dimethylarginine dimethylaminohydrolase (DDAH) to form L-citrulline and dimethylamine $[3,4]$. DDAH activity is affected by certain metabolites (e.g. L-arginine, NO and reactive oxygen species) and by genetic factors [3]. Several functional single nucleotide polymorphisms (SNPs) in DDAH genes influencing enzyme activity have been identified and associated with several clinical disorders [5-8].

A number of morbidities affecting cardiovascular system [9-12], metabolism [13$16]$ and kidneys $[17,18]$ were associated with elevated circulating ADMA levels. In most of these disorders ADMA has been identified as a predictor of cardiovascular event or allcause mortality in general population [19-23]. Studies focusing specifically on diabetic subjects [24] are less consistent. Several authors reported that elevated ADMA levels predict cardiovascular morbidity and mortality [25-27] and in some of these studies ADMA also affected progression of chronic kidney disease (CKD) in type 1 diabetes mellitus (T1DM) [25] and DN in type 2 diabetes mellitus (T2DM) [26, 28]. Importantly, all mentioned studies in diabetic populations considered clinical end-points (cardiovascular and renal) as isolated events. Recent publications however suggest that SDMA could possibly have a similar or even better predictive value for renal events as ADMA due to its exclusive renal clearance $[29,30]$.

Considering the complexity of processes responsible for metabolism and turnover of methylarginines (i.e. differences in production and degradation rate of various methylarginines, genetic variability in DDAH genes possibly influencing enzyme activity and crucial role of kidneys in their clearance) we wanted to comprehensively reassess the eventual relationships between those potentially relevant parameters (i.e. ADMA, SDMA, L-arginine, L-arginine/ADMA ratio and selected DDAH SNPs) and the risk of diabetic nephropathy progression in a prospectively followed cross-sectional cohort of diabetic patients. The aim of the study was to ascertain predictive potential of biochemical and genetic parameters studied for the progression of diabetic kidney disease using competing risk analysis as more clinically realistic alternative to commonly used time-to event analysis. 


\section{Kidney Blood Pressure Research}

Kidney Blood Press Res 2012;36:200-208

\begin{tabular}{l|l}
\hline DOI: $10.1159 / 000343409$ & (C) 2012 S. Karger AG, Basel
\end{tabular}

Published online: November 11, 2012

www.karger.com/kbr

Tanhäuserová/Tomandl/Pácal et al.: Methylated Arginines are Predictors of Diabetic Nephropathy Progression

\section{Materials and Methods}

\section{Subjects}

The cross-sectional study comprised 341 unrelated Caucasian subjects from South Moravia region of Czech Republic with diabetes duration at least 10 years (177 men and 164 women), 89 subjects had T1DM, 252 subjects had T2DM. The stage of DN was defined according to the urinary albumin excretion (UAE) and stage of CKD by glomerular filtration rate (GFR) assessed by creatinine clearance (based on 24 hrs urine collection). Both parameters - UAE and GFR - were measured at least once in 6 months or more often, staging for DN and CKD was based on two consecutive values. Our entire study sample consisted of: normoalbuminuric subjects (UAE $<30 \mathrm{mg} / 24 \mathrm{~h}, n=71$ ), microalbuminuric subjects (UAE 30-300mg/24h, $n=115$ ) and proteinuric subjects (UAE $>300 \mathrm{mg} / 24 \mathrm{~h}, n=155$ ). The representation of DN stages in T1DM and T2DM subjects were as follows: normoalbuminuria $48.3 \%$ and $11.1 \%$, respectively, microalbuminuria $19.1 \%$ a $38.9 \%$, respectively and proteinuria $32.6 \%$ and $50 \%$, respectively.

Respective staging for CKD in the same sample was: CKD I (GFR $\geq 90 \mathrm{ml} / \mathrm{min}$ per $1.73 \mathrm{~m}^{2}, 30.4 \%$ ), CKD II (60-89 ml/min per $1.73 \mathrm{~m}^{2}, 20.3 \%$ ), CKD III (30-59 ml/min per $\left.1.73 \mathrm{~m}^{2}, 33.7 \%\right)$, CKD IV (15-29 ml/ min per $1.73 \mathrm{~m}^{2}, 13.3 \%$ ), subjects with CKD V at baseline (GFR $<15 \mathrm{ml} / \mathrm{min}$ per $1.73 \mathrm{~m}^{2}$ or maintenance haemodialysis, $2.3 \%$ ) were not included since further progression is not possible. Decline of GFR ( $\Delta$ GFR) over the follow-up period was calculated as a difference between baseline and follow-up GFR values. Study participant's characteristics are summarized in Table 1. Informed consent was obtained from each patient prior to being included in the study. The study was performed according to the recommendations of the Declaration of Helsinki and approved by the Ethical Committee of Medical Faculty, Masaryk University Brno.

\section{Analysed material and methods}

Sample of peripheral venous blood was taken from each subject at the time of enrolment in the study. Blood samples were centrifuged immediately after collection at $3000 \mathrm{~g}$ for 10 minutes. DNA was extracted from separated peripheral blood leukocytes by the phenol-chloroform method and together with plasma frozen and stored at $-20^{\circ} \mathrm{C}$ or $-80^{\circ} \mathrm{C}$, respectively, until further analysis. DNA was available from all studied subjects, plasma from 141 patients (a subset which however did not differed significantly from the whole sample as explicitly tested). Plasma levels of ADMA, SDMA and L-arginine were measured using highperformance liquid chromatography with fluorescence detection as described previously [31]. The intraand inter-assay coefficients of variation were $<2 \%$ and $4 \%$, respectively. For genetic analysis tagging SNPs in the DDAH1 (chromosome 1p22) and DDAH2 (chromosome 6p21.3) genes were selected using HapMap [32] according to the following criteria: minor allele frequency $>10 \%$ in Caucasian population and pairwise $r^{2}>0.8$ with any of the unselected SNP. Specifically we have selected SNPs rs986639, rs7521189, rs669173, rs17384213 in DDAH1 and rs805305, rs805304 in DDAH2. PCR with the fluorescent-based chemistry was used to determine DDAH1 SNPs (TaqMan ${ }^{\circledR}$ SNP Genotyping Assay, Applied Biosystems). Detection methods (primers and restriction enzymes) for DDAH2 SNPs were designed; details can be obtained from authors.

\section{Follow-up}

For the follow-up analysis we considered progression of DN defined as a transition from any given baseline DN stage to a more advanced stage of albuminuria or to ESRD (based on two consecutive measurements of UAE in min. 6 month interval) as a primary outcome and all-cause mortality (ACM) as a competing event. Complete follow-up information was available from all study participants with the followup median 40 [26-59] months.

\section{Statistical analysis}

Data are expressed as median [interquartile range] or as percentages. Differences in continuous variables between the groups were analysed using Mann-Whitney test or Kruskal-Wallis ANOVA. For each SNP, differences in genotype distributions and Hardy-Weinberg equilibrium were tested by a $\chi^{2}$ test and differences in allele frequencies were tested by a two-tail Fisher-exact test. Haplotypes were constructed in silico by software PHASE [33]. Differences in haplotype frequencies between groups were determined empirically by permutation test (5000 permutations). Spearman correlation coefficient was used to describe relationships between continuous variables. Standard competing risk methodology focusing on cumulative incidence was adopted for the nonparametric estimation and modelling of associations of the 


\section{Kidney \\ Blood Pressure Research}

\begin{tabular}{l}
\hline \multicolumn{2}{|l}{ Kidney Blood Press Res 2012;36:200-208 } \\
\hline \begin{tabular}{l|l} 
DOI: $10.1159 / 000343409$ \\
Published online: November 11, 2012 & $\begin{array}{l}\text { C } 2012 \text { S. Karger AG, Basel } \\
\text { www.karger.com/kbr }\end{array}$
\end{tabular}
\end{tabular}

Tanhäuserová/Tomandl/Pácal et al.: Methylated Arginines are Predictors of Diabetic Nephropathy Progression

Table 1: Basic clinical and biochemical characteristics of the subjects

\begin{tabular}{|c|c|c|c|c|}
\hline Parameter (unit) & $\begin{array}{l}\text { Normoalbuminuria } \\
(n=71)\end{array}$ & $\begin{array}{l}\text { Microalbuminuria } \\
(n=115)\end{array}$ & $\begin{array}{l}\text { Proteinuria } \\
(n=155)\end{array}$ & $P$ \\
\hline Age (years) & $52[36-64]$ & $66[56-75]$ & $65[60-74]$ & $<0.001$ \\
\hline Duration of diabetes (years) & $16[11-23]$ & $11[7-19]$ & $17[10-22]$ & $<0.001$ \\
\hline FPG (mmol/l) & $7.2[5.7-8.3]$ & $7.5[5.7-9.0]$ & $7.7[5.8-9.4]$ & 0.003 \\
\hline $\mathrm{HbA}_{1 \mathrm{c}}(\%)$ & $7.3[5.7-8.3]$ & $7.4[5.4-9.0]$ & $7.9[5.8-9.4]$ & 0.391 \\
\hline Triglycerides (mmol/l) & $1.33[0.83-2.00]$ & $2.00[1.36-2.90]$ & $2.10[1.50-3.20]$ & $<0.001$ \\
\hline Total cholesterol (mmol/l) & $4.82[4.34-5.30]$ & $4.90[4.29-5.50]$ & $5.08[4.30-6.00]$ & 0.376 \\
\hline Creatinine $(\mu \mathrm{mol} / \mathrm{l})$ & $91[82-103]$ & $114[89-152]$ & $145[114-220]$ & $<0.001$ \\
\hline Proteinuria (g/24 hours) & $0.096[0.075-0.114]$ & $0.140[0.090-0.210]$ & $1.290[0.550-2.938]$ & $<0.001$ \\
\hline GFR $\left(\mathrm{ml} / \mathrm{min}\right.$ per $\left.1.73 \mathrm{~m}^{2}\right)$ & $107.40[84.39-129.78]$ & 62.88 [42.24-96.84] & $46.83[30.81-77.46]$ & $<0.001$ \\
\hline UAE (mg/24 hours) & $8[6-13]$ & $36[18-140]$ & $345[97-606]$ & $<0.001$ \\
\hline Prevalence of retinopathy $(\%)$ & 56.3 & 40.9 & 56.8 & 0.024 \\
\hline Insulin $(\%)$ & 74.6 & 49.6 & 69.0 & $<0.001$ \\
\hline Oral anti-diabetic drugs (\%) & 22.5 & 49.6 & 38.7 & 0.001 \\
\hline ACE inhibitors (\%) & 42.3 & 67.8 & 61.9 & 0.002 \\
\hline AT2R blockers (\%) & 8.5 & 36.5 & 56.8 & $<0.001$ \\
\hline \multirow[t]{2}{*}{ Dual RAS blockade (\%) } & 4.2 & 22.6 & 38.7 & $<0.001$ \\
\hline & $(n=29)$ & $(n=27)$ & $(n=85)$ & \\
\hline $\operatorname{ADMA}(\mu \mathrm{mol} / \mathrm{l})^{\mathrm{a}}$ & $0.36[0.31-0.39]$ & $0.41[0.38-0.45]$ & $0.41[0.37-0.46]$ & $<0.001$ \\
\hline $\operatorname{SDMA}(\mu \mathrm{mol} / \mathrm{l})^{\mathrm{a}}$ & $0.34[0.31-0.40]$ & $0.59[0.36-0.82]$ & $0.70[0.51-1.04]$ & $<0.001$ \\
\hline L-Arginine $(\mu \mathrm{mol} / 1)^{\mathrm{a}}$ & $46.5[31.9-60.1]$ & $36.7[28.0-49.2]$ & $45.8[34.8-56.8]$ & 0.136 \\
\hline L-Arginine/ADMA ratio ${ }^{\mathrm{a}}$ & $150.6[90.1-173.6]$ & $91.5[62.0-127.0]$ & $113.6[86.9-138.3]$ & 0.022 \\
\hline \multicolumn{5}{|c|}{$\begin{array}{l}\text { Data are expressed as median [interquartile range] or percentage. Comparisons made by Kruskal-Wallis ANOVA and Pearsons } \\
\text { chi-square test. aOriginal values unadjusted to GFR. Abbreviations: ACE, angiotensin-converting enzyme; ADMA, asymmetric } \\
\text { dimethylarginine; AT2R, angiotensin II type } 2 \text { receptor; ESRD, end stage renal disease; FPG, fasting plasma glucose; RAS, } \\
\text { renin-angiotensin-aldosterone system: SDMA, symmetric dimethylarginine: UAE urinary albumin excretion }\end{array}$} \\
\hline
\end{tabular}

potential risk factors and the progression of DN and ACM. Gray test [34] was used to assess the differences in cumulative incidence of the competing risks with respect to the risk factors, and Fine and Gray model [35] was used to evaluate the predictive potential of the considered parameters. For all standard analysis Statistica for Windows (Statsoft Inc., Tulsa, OK, USA) was used. Bonferroni correction $\left(P_{\text {corr }} \leq 0.05 /\right.$ number of tests) was used to adjust for multiple comparisons where appropriate, otherwise $P \leq 0.05$ was considered statistically significant.

\section{Results}

\section{Analysis of baseline data}

Plasma levels of ADMA, SDMA, L-arginine and calculated L-arginine/ADMA ratio are shown in Table 1 . To evaluate the relationships between markers studied and the kidney function we computed Spearman correlation coefficients $\left(P_{\text {corr }} \leq 0.0042\right)$. We found a significant negative correlations between ADMA, SDMA and GFR $(r=-0.41$ and -0.78 , respectively; both $P<0.000001$ ) and significant positive correlation between ADMA, SDMA and serum creatinine levels ( $r=0.40$ and 0.80 , respectively; both $P \leq 0.000001)$. Finally, we detected a positive correlation between SDMA and proteinuria $(r=0.32, P<0.0003)$.

Genotype and allele frequencies of studied SNPs were compared between all subjects with DN (i.e. microalbuminuria, and proteinuria pooled in a single group, $n=270$ ) and subjects without DN (i.e. normoalbuminuria, $n=71$ ). Linkage disequilibrium (LD) analysis using JLIN software [36] revealed strong linkage between SNPs in the DDAH2 gene $\left(\mathrm{r}^{2}=0.99\right.$, $D^{\prime}=1.0$ ) therefore only one representative SNP rs805304 was included in subsequent genetic analyses. We found nominally significant differences in genotype and allele frequencies of DDAH2 SNP rs805304 ( $P=0.041$ and 0.042, respectively) between DN and non-DN group, however significance was lost after Bonferroni correction $\left(P_{\text {corr }} \leq 0.01\right)$. Comparison of constructed DDAH1 haplotypes between groups of patients with and without DN did not show the difference $(P>0.05,5000$ permutations). 


\section{Kidney \\ Blood Pressure Research}

Tanhäuserová/Tomandl/Pácal et al.: Methylated Arginines are Predictors of Diabetic Nephropathy Progression

Table 2: Fine and Gray model: the effect of patient and disease characteristics on the progression of $\mathrm{DN}(n=341)$

\begin{tabular}{llllll}
\hline \multirow{2}{*}{ Risk factor } & \multirow{2}{*}{ Risk category } & \multirow{2}{*}{ Basal category } & \multicolumn{3}{l}{ Fine and Gray model } \\
\cline { 4 - 6 } & & & HR & $95 \%$ CI & $P$-value \\
\hline Age & $\geq 60$ years & $<60$ years & 1.31 & $0.82-2.09$ & 0.260 \\
Sex & Female & Male & 1.29 & $0.82-2.04$ & 0.270 \\
DM duration & $\geq 15$ years & $<15$ years & 1.46 & $0.92-2.32$ & 0.110 \\
Stage of kidney disease & Microalbuminuria & Normoalbuminuria & 3.10 & $1.33-7.24$ & $0.009^{\mathrm{a}}$ \\
Stage of kidney disease & Proteinuria & Normoalbuminuria & 2.82 & $1.23-6.46$ & $0.014^{\mathrm{a}}$ \\
rs805304 $(\mathrm{AA}, \mathrm{AC}, \mathrm{CC})$ & AC,CC & AA & 1.03 & $0.65-1.63$ & 0.910 \\
\hline
\end{tabular}

a Statistically significant result $(P=0.05)$. Abbreviations: DM, diabetes mellitus; DN, diabetic nephropathy

Table 3: Fine and Gray model: effect of biochemical markers on the progression of DN $(n=141)$

\begin{tabular}{|c|c|c|c|c|c|}
\hline \multirow{2}{*}{ Risk factor } & \multirow{2}{*}{ Risk category } & \multirow{2}{*}{ Basal category } & \multicolumn{3}{|c|}{ Fine and Gray model } \\
\hline & & & $\mathrm{HR}$ & $95 \% \mathrm{CI}$ & $P$-value \\
\hline SDMA/GFR ratio & $\geq 0.60$ & $<0.60$ & 5.15 & $1.77-15.00$ & $0.003^{\mathrm{a}}$ \\
\hline Stage of kidney disease & $\begin{array}{l}\text { Microalbuminuria } \\
\text { proteinuria }\end{array}$ & Normoalbuminuria & 3.21 & $0.41-25.50$ & 0.270 \\
\hline ADMA/GFR ratio & $\geq 0.40$ & $<0.40$ & 7.60 & $2.17-26.70$ & $0.002^{\mathrm{a}}$ \\
\hline Stage of kidney disease & $\begin{array}{l}\text { Microalbuminuria } \\
\text { proteinuria }\end{array}$ & Normoalbuminuria & 2.13 & $0.24-18.70$ & 0.490 \\
\hline L-arginine/ADMA/GFR ratio & $\geq 114$ & $<114$ & 3.68 & $1.53-8.86$ & $0.004^{\mathrm{a}}$ \\
\hline Stage of kidney disease & $\begin{array}{l}\text { Microalbuminuria } \\
\text { proteinuria }\end{array}$ & Normoalbuminuria & 7.26 & $0.89-59.01$ & 0.064 \\
\hline
\end{tabular}

Since the activity of DDAH enzymes may influence plasma ADMA level and enzyme activity could be affected by genetic variability we tested for eventual genotype - phenotype associations. Only a subset of subjects with mild to moderate CKD (GFR $\geq 30 \mathrm{ml} / \mathrm{min}$ per 1.73 $\mathrm{m}^{2}, n=115$ ) was included in this particular analysis (since ADMA levels reflect decreased renal function in subjects with advanced stages of CKD). We did not find any significant differences in ADMA levels between genotypes of studied SNPs.

\section{Follow-up analysis}

At the end of follow-up cumulative incidence of DN progression was $22.6 \%$ (of these $7.8 \%$ progressed from normo- to microalbuminuria, $1.2 \%$ from normo- to macroalbuminuria, $32.5 \%$ from micro- to macroalbuminuria, $13 \%$ from microalbuminuria to ESRD and $45.5 \%$ from macroalbuminuria to ESRD) and ACM $15.2 \%$ during the follow-up period. Competing risk analysis (cumulative incidence-based methodology) considered progression of DN and ACM as competing risks. We first performed univariate analysis to test for an eventual statistically significant effect of any relevant variable (age at the time of enrolment, sex, diabetes duration, inception stage of DN, SNPs in DDAH1 and 2, ADMA, SDMA, L-arginine/ ADMA ratio (all standardized to GFR), presence of retinopathy, treatment with insulin, oral anti-diabetic drugs, ACE inhibitors and AT2R blockers) on the cumulative incidence of the two competing events. Inception stage of DN appeared significant risk factor for both progression of DN and ACM $(P=0.017$ and 0.010 , respectively). For ACM, age at the time of enrolment ( $<60$ vs. $\geq 60$ years) and SNP rs805304 in DDAH2 (AA genotype) were identified as significant risks too $(P=0.013$ and 0.048 , respectively). In case of DN progression statistically significant effects were identified for all biochemical markers studied (adjusted for GFR since they strongly correlate with GFR): ADMA $(P<0.001)$, SDMA $(P<0.001)$ and L-arginine/ADMA ratio $(P=0.002)$. 


\section{Kidney Blood Pressure Research}

Kidney Blood Press Res 2012;36:200-208

\begin{tabular}{l|l}
\hline DOI: $10.1159 / 000343409$ & C 2012 S. Karger AG, Basel
\end{tabular}

Published online: November 11, 2012

www.karger.com $/ \mathrm{kbr}$

Tanhäuserová/Tomandl/Pácal et al.: Methylated Arginines are Predictors of Diabetic Nephropathy Progression

Based on previous analysis multivariate competing risk analysis was then performed with the aim to assess the prognostic potential of parameters available in all 341 subjects for the cumulative incidence of DN progression, see Table 2. Fine and Gray model indicated inception stage of kidney disease as a dominant independent prognostic factor. The estimated hazard ratios were similar for both microalbuminuria and proteinuria. Hypothetical contribution of genetic variability was lost in the multivariate comparison. In Fine and Gray model considering the role of biochemical markers previously identified by univariate analysis against the stage of kidney disease (this analysis comprised a subset of 141 subjects with plasma parameters available), see Table 3 , we identified ADMA/GFR ratio $(P=0.002)$, SDMA/GFR ratio $(P=0.003)$ and L-arginine/ADMA/GFR ratio $(P=0.004)$ as significant and much stronger predictors of DN progression than the inception stage.

Finally, we ascertained the rate of decline of renal function (i.e. progression of CKD) estimated by $\triangle$ GFR and analysed eventual contribution of DDAH1 and DDAH2 SNPs to $\triangle$ GFR and predictive value of baseline ADMA, SDMA or L-arginine/ADMA ratio for $\triangle$ GFR in our study sample. The median [interquartile range] $\triangle$ GFR in normo-, micro- and macroalbuminuria groups were: 0 [0 - 12.6] $\mathrm{ml} / \mathrm{min}$ per $1.73 \mathrm{~m}^{2}, 5.73[0-21.78] \mathrm{ml} / \mathrm{min}$ per $1.73 \mathrm{~m}^{2}$ and $11.7[1.32-26.94] \mathrm{ml} / \mathrm{min}$ per $1.73 \mathrm{~m}^{2}$, respectively. There were no statistically significant differences in $\triangle$ GFR between genotypes of any of the SNPs in DDAH1 or DDAH2 $(P>0.05$, Kruskal-Wallis ANOVA). Furthermore, groups defined by median values of baseline ADMA, SDMA or L-arginine/ADMA ratio $(0.41 \mu \mathrm{mol} / \mathrm{l}, 0.63 \mu \mathrm{mol} / \mathrm{l}$ and 113.6 , respectively $)$ did not significantly differ in their respective $\triangle$ GFR $(P>0.05$, Mann-Whitney).

\section{Discussion}

In the present study we adopted competing risk methodology to evaluate the predictive potential of clinical, biochemical and genetic markers related to the metabolism of methylarginines for renal outcome in diabetic patients. We believe the use of competing risk analysis is more appropriate in the real clinical context - presence of two endpoints/ competing events in our study design when the occurrence of one outcome affects the probability of the others.

In the cross-sectional part of our study we found tight correlation between SDMA and GFR confirming that SDMA is almost entirely eliminated by the kidneys and its plasma level primarily reflects renal function. Our observations are in line with large meta-analysis that established SDMA as reliable marker of renal function [30]. Similarly, ADMA levels correlated with GFR, a finding that corroborated previous on T1DM subjects [27]. Strong relationship between ADMA and GFR is seemingly in discrepancy with the fact that ADMA is supposed to be eliminated predominantly by enzymatic degradation (DDAH) which means that it cannot be generally considered a marker of kidney function. One possible explanation was provided by the study showing that hyperglycaemia suppresses DDAH activity in vitro [37].

Alternatively, genetic variation in relevant genes may be involved. To address whether polymorphisms in DDAH genes could affect enzyme activity we compared ADMA levels between carriers of individual genotypes in DDAH1 and 2 loci in subjects with preserved renal function with no significant differences identified. Contrary to our lack of genotypephenotype association rs17384213 has recently been associated with plasma ADMA level (healthy subjects as well as patients with CKD with G allele had lower plasma ADMA) and also with DDAH1 mRNA expression in the kidney allografts [7]. Furthermore, five DDAH SNPs have been associated with serum ADMA level in T2DM [8]. Finally, recent study did not find any association between 36 tagging SNPs in DDAH1 and 2 genes and serum ADMA level in T1DM subjects [38]. Taken together, it is thought that genetic variability in DDAH genes might be involved in the regulation of enzyme activity to certain extent, however there are no convincing data currently to support biologically relevant role of genetic variability in DDAH in clinical settings. 


\section{Kidney \\ Blood Pressure Research}

Kidney Blood Press Res 2012;36:200-208

\begin{tabular}{l|l}
\hline DOI: $10.1159 / 000343409$ & (c) 2012 S. Karger AG, Basel
\end{tabular}

Published online: November 11, 2012

www.karger.com/kbr

Tanhäuserová/Tomandl/Pácal et al.: Methylated Arginines are Predictors of Diabetic Nephropathy Progression

To our knowledge no study was carried out so far to ascertain relationship between DDAH genetic variability and clinical phenotype of DN. Similarly, the role of DDAH polymorphisms in the progression of DN was not investigated yet too. Interestingly DDAH2 gene lies in the genomic region 6 p21.3 previously identified as a risk factor for DN [39]. Of all studied variants in DDAH 1 and 2 genes in a present study we found borderline association of DDAH2 SNP rs805304 with DN but not with the risk of its progression.

In the prospective part of the study we initially identified the stage of kidney disease - both micro- and macroalbuminuria as compared to normoalbuminuria - as a strong independent clinical predictor of DN progression. This finding is not surprising since progression of renal disease is not linear, the more advanced stage the more pathogenic factors present for further development. Importantly, all biochemical markers adjusted to GFR - i.e. ADMA, SDMA and L-arginine/ADMA ratio - constituted even stronger predictors of DN progression than the inception stage of kidney disease. Given the stage of DN, plasma values of methylarginines act as potent predictors of DN progression independent on subject's renal function. At the same time, decline of GFR documented over the follow-up period does not seem to be explained neither by DDAH1 or 2 genetic variability nor baseline ADMA, SDMA or L-arginine/ADMA ratio.

Numerous studies to date identified ADMA as a risk factor of mortality [19, 27,40] not only in subject with diabetes and/or cardiovascular disease but also in general population [41]. Only one study so far on Japanese population analysed ADMA in diabetics with renal disease and identified it as a significant predictor of DN. In the present study we confirmed that ADMA (together with SDMA) serve as predictor of DN progression in European population [28]. Of course this interpretation has limitations at present. Number of subject having complete biochemical data available is relatively small (but comparable with other studies) which may be problematic especially in the prospective part of the study where low number of events (DN progressions) might make comparisons of weight of risks problematic. Such approach has to be certainly repeated on different data sets.

Putative role of genetic polymorphism in the determination of the rate of DN progression was not confirmed. While other authors described association of AA genotype of the SNP rs805304 with hypertension [6] and cardiovascular disease [42] this SNP initially exhibiting marginal effect on ACM and the only one studied in multivariate analysis was not significantly associated with DN progression in our study.

In conclusion, results of our study demonstrate that plasma levels of endogenous methylarginines strongly correlate with the stage of diabetic kidney disease. Furthermore, after standardisation for GFR they can still be considered reliable biomarkers of progression of DN independent on given stage of DN.

\section{Conflict of Interests}

None declared.

\section{Acknowledgements}

Supported by grant NT11405 from the Ministry of Health of Czech Republic.

\section{References}

1 Siervo M, Corander M, Stranges S, Bluck L: Post-challenge hyperglycaemia, nitric oxide production and endothelial dysfunction: The putative role of asymmetric dimethylarginine (adma). Nutr Metab Cardiovasc Dis 2011;21:1-10. 


\section{Kidney \\ Blood Pressure Research}

Kidney Blood Press Res 2012;36:200-208

\begin{tabular}{l|l}
\hline DOI: $10.1159 / 000343409$ & (c) 2012 S. Karger AG, Basel
\end{tabular}

Published online: November 11, 2012

www.karger.com/kbr

Tanhäuserová/Tomandl/Pácal et al.: Methylated Arginines are Predictors of Diabetic Nephropathy Progression

2 Teerlink T, Luo Z, Palm F, Wilcox CS: Cellular adma: Regulation and action. Pharmacol Res 2009;60:448460.

-3 Palm F, Onozato ML, Luo Z, Wilcox CS: Dimethylarginine dimethylaminohydrolase (ddah): Expression, regulation, and function in the cardiovascular and renal systems. Am J Physiol Heart Circ Physiol 2007;293:H3227-3245.

4 Leiper JM, Santa Maria J, Chubb A, MacAllister RJ, Charles IG, Whitley GS, Vallance P: Identification of two human dimethylarginine dimethylaminohydrolases with distinct tissue distributions and homology with microbial arginine deiminases. Biochem J 1999;343:209-214.

5 Jones LC, Tran CT, Leiper JM, Hingorani AD, Vallance P: Common genetic variation in a basal promoter element alters ddah2 expression in endothelial cells. Biochem Biophys Res Commun 2003;310:836-843.

6 Maas R, Erdmann J, Luneburg N, Stritzke J, Schwedhelm E, Meisinger C, Peters A, Weil J, Schunkert H, Boger RH, Lieb W: Polymorphisms in the promoter region of the dimethylarginine dimethylaminohydrolase 2 gene are associated with prevalence of hypertension. Pharmacol Res 2009;60:488-493.

7 Caplin B, Nitsch D, Gill H, Hoefield R, Blackwell S, MacKenzie D, Cooper JA, Middleton RJ, Talmud PJ, Veitch P, Norman J, Wheeler DC, Leiper JM: Circulating methylarginine levels and the decline in renal function in patients with chronic kidney disease are modulated by ddah1 polymorphisms. Kidney Int 2010;77:459467.

8 Abhary S, Burdon KP, Kuot A, Javadiyan S, Whiting MJ, Kasmeridis N, Petrovsky N, Craig JE: Sequence variation in ddah1 and ddah2 genes is strongly and additively associated with serum adma concentrations in individuals with type 2 diabetes. PLoS One, DOI: 10.1371/journal.pone.0009462.

-9 Boger RH, Bode-Boger SM, Thiele W, Junker W, Alexander K, Frolich JC: Biochemical evidence for impaired nitric oxide synthesis in patients with peripheral arterial occlusive disease. Circulation 1997;95:20682074.

10 Schulze F, Lenzen H, Hanefeld C, Bartling A, Osterziel KJ, Goudeva L, Schmidt-Lucke C, Kusus M, Maas R, Schwedhelm E, Strodter D, Simon BC, Mugge A, Daniel WG, Tillmanns H, Maisch B, Streichert T, Boger RH: Asymmetric dimethylarginine is an independent risk factor for coronary heart disease: Results from the multicenter coronary artery risk determination investigating the influence of adma concentration (cardiac) study. Am Heart J, DOI: 10.1016/j.ahj.2006.06.005.

-11 Valkonen VP, Paiva H, Salonen JT, Lakka TA, Lehtimaki T, Laakso J, Laaksonen R: Risk of acute coronary events and serum concentration of asymmetrical dimethylarginine. Lancet 2001;358:2127-2128.

12 Surdacki A, Nowicki M, Sandmann J, Tsikas D, Boeger RH, Bode-Boeger SM, Kruszelnicka-Kwiatkowska O, Kokot F, Dubiel JS, Froelich JC: Reduced urinary excretion of nitric oxide metabolites and increased plasma levels of asymmetric dimethylarginine in men with essential hypertension. J Cardiovasc Pharmacol 1999;33:652-658.

13 Stuhlinger MC, Abbasi F, Chu JW, Lamendola C, McLaughlin TL, Cooke JP, Reaven GM, Tsao PS: Relationship between insulin resistance and an endogenous nitric oxide synthase inhibitor. Jama 2002;287:1420-1426.

14 Abbasi F, Asagmi T, Cooke JP, Lamendola C, McLaughlin T, Reaven GM, Stuehlinger M, Tsao PS: Plasma concentrations of asymmetric dimethylarginine are increased in patients with type 2 diabetes mellitus. Am J Cardiol 2001;88:1201-1203.

-15 Krzyzanowska K, Mittermayer F, Shnawa N, Hofer M, Schnabler J, Etmuller Y, Kapiotis S, Wolzt M, Schernthaner G: Asymmetrical dimethylarginine is related to renal function, chronic inflammation and macroangiopathy in patients with type 2 diabetes and albuminuria. Diabet Med 2007;24:81-86.

-16 Altinova AE, Arslan M, Sepici-Dincel A, Akturk M, Altan N, Toruner FB: Uncomplicated type 1 diabetes is associated with increased asymmetric dimethylarginine concentrations. J Clin Endocrinol Metab 2007;92:1881-1885.

-17 Vallance P, Leone A, Calver A, Collier J, Moncada S: Accumulation of an endogenous inhibitor of nitric oxide synthesis in chronic renal failure. Lancet 1992;339:572-575.

18 Jacobi J, Tsao PS: Asymmetrical dimethylarginine in renal disease: Limits of variation or variation limits? A systematic review. Am J Nephrol 2008;28:224-237.

19 Ravani P, Tripepi G, Malberti F, Testa S, Mallamaci F, Zoccali C: Asymmetrical dimethylarginine predicts progression to dialysis and death in patients with chronic kidney disease: A competing risks modeling approach. J Am Soc Nephrol 2005;16:2449-2455.

20 Zoccali C, Bode-Boger S, Mallamaci F, Benedetto F, Tripepi G, Malatino L, Cataliotti A, Bellanuova I, Fermo I, Frolich J, Boger R: Plasma concentration of asymmetrical dimethylarginine and mortality in patients with end-stage renal disease: A prospective study. Lancet 2001;358:2113-2117. 


\section{Kidney \\ Blood Pressure Research}

Kidney Blood Press Res 2012;36:200-208

\begin{tabular}{l|l}
\hline DOI: $10.1159 / 000343409$ & (c) 2012 S. Karger AG, Basel
\end{tabular}

Published online: November 11, 2012

www.karger.com/kbr

Tanhäuserová/Tomandl/Pácal et al.: Methylated Arginines are Predictors of Diabetic Nephropathy Progression

-21 Leong T, Zylberstein D, Graham I, Lissner L, Ward D, Fogarty J, Bengtsson C, Bjorkelund C, Thelle D: Asymmetric dimethylarginine independently predicts fatal and nonfatal myocardial infarction and stroke in women: 24-year follow-up of the population study of women in gothenburg. Arterioscler Thromb Vasc Biol 2008;28:961-967.

-22 Wolf C, Lorenzen JM, Stein S, Tsikas D, Stork S, Weidemann F, Ertl G, Anker SD, Bauersachs J, Thum T: Urinary asymmetric dimethylarginine (adma) is a predictor of mortality risk in patients with coronary artery disease. Int J Cardiol 2012;156:289-294.

-23 Fliser D, Kronenberg F, Kielstein JT, Morath C, Bode-Boger SM, Haller H, Ritz E: Asymmetric dimethylarginine and progression of chronic kidney disease: The mild to moderate kidney disease study. J Am Soc Nephrol 2005;16:2456-2461.

-24 Anderssohn M, Schwedhelm E, Luneburg N, Vasan RS, Boger RH: Asymmetric dimethylarginine as a mediator of vascular dysfunction and a marker of cardiovascular disease and mortality: An intriguing interaction with diabetes mellitus. Diab Vasc Dis Res 2010;7:105-118.

25 Lajer M, Tarnow L, Jorsal A, Teerlink T, Parving HH, Rossing P: Plasma concentration of asymmetric dimethylarginine (adma) predicts cardiovascular morbidity and mortality in type 1 diabetic patients with diabetic nephropathy. Diabetes Care 2008;31:747-752.

-26 Krzyzanowska K, Mittermayer F, Wolzt M, Schernthaner G: Asymmetric dimethylarginine predicts cardiovascular events in patients with type 2 diabetes. Diabetes Care 2007;30:1834-1839.

27 Tarnow L, Hovind P, Teerlink T, Stehouwer CD, Parving HH: Elevated plasma asymmetric dimethylarginine as a marker of cardiovascular morbidity in early diabetic nephropathy in type 1 diabetes. Diabetes Care 2004;27:765-769.

-28 Hanai K, Babazono T, Nyumura I, Toya K, Tanaka N, Tanaka M, Ishii A, Iwamoto Y: Asymmetric dimethylarginine is closely associated with the development and progression of nephropathy in patients with type 2 diabetes. Nephrol Dial Transplant 2009;24:1884-1888.

29 Kiechl S, Lee T, Santer P, Thompson G, Tsimikas S, Egger G, Holt DW, Willeit J, Xu Q, Mayr M: Asymmetric and symmetric dimethylarginines are of similar predictive value for cardiovascular risk in the general population. Atherosclerosis 2009;205:261-265.

-30 Kielstein JT, Salpeter SR, Bode-Boeger SM, Cooke JP, Fliser D: Symmetric dimethylarginine (sdma) as endogenous marker of renal function--a meta-analysis. Nephrol Dial Transplant 2006;21:2446-2451.

-31 de Jong S, Teerlink T: Analysis of asymmetric dimethylarginine in plasma by hplc using a monolithic column. Anal Biochem 2006;353:287-289.

32 Consortium TIH: The international hapmap project. Nature 2003;426:789-796.

-33 Stephens M, Smith NJ, Donnelly P: A new statistical method for haplotype reconstruction from population data. Am J Hum Genet 2001;68:978-989.

-34 Gray RJ: A class of k-sample tests for comparing the cumulative incidence of a competing risk. The Annals of Statistics 1988;16:1141-1154.

-35 Fine JP GR: A proportional hazards model for the subdistribution of a competing risk. Journal of the American Statistical Association 1999;94:496-509.

-36 Carter KW, McCaskie PA, Palmer LJ: Jlin: A java based linkage disequilibrium plotter. BMC Bioinformatics 2006;7:60.

37 Lin KY, Ito A, Asagami T, Tsao PS, Adimoolam S, Kimoto M, Tsuji H, Reaven GM, Cooke JP: Impaired nitric oxide synthase pathway in diabetes mellitus: Role of asymmetric dimethylarginine and dimethylarginine dimethylaminohydrolase. Circulation 2002;106:987-992.

-38 Fogarty RD, Abhary S, Javadiyan S, Kasmeridis N, Petrovsky N, Whiting MJ, Craig JE, Burdon KP: Relationship between ddah gene variants and serum adma level in individuals with type 1 diabetes. J Diabetes Complications 2012;26:195-198.

39 Kankova K, Stejskalova A, Pacal L, Tschoplova S, Hertlova M, Krusova D, Izakovicova-Holla L, Beranek M, Vasku A, Barral S, Ott J: Genetic risk factors for diabetic nephropathy on chromosomes 6p and 7q identified by the set-association approach. Diabetologia 2007;50:990-999.

-40 Aucella F, Maas R, Vigilante M, Tripepi G, Schwedhelm E, Margaglione M, Gesualdo L, Boeger R, Zoccali C: Methylarginines and mortality in patients with end stage renal disease: A prospective cohort study. Atherosclerosis 2009;207:541-545.

41 Boger RH, Sullivan LM, Schwedhelm E, Wang TJ, Maas R, Benjamin EJ, Schulze F, Xanthakis V, Benndorf RA, Vasan RS: Plasma asymmetric dimethylarginine and incidence of cardiovascular disease and death in the community. Circulation 2009;119:1592-1600.

42 Gad MZ, Hassanein SI, Abdel-Maksoud SM, Shaban GM, Abou-Aisha K: Association of ddah2 gene

polymorphism with cardiovascular disease in egyptian patients. J Genet 2011;90:161-163. 